\title{
Gambaran Kepuasan Kerja pada Pengemudi Layanan Jasa Transportasi Ojek Online
}

\author{
Fajar Trisna Sanubari ${ }^{1}$, Sofa Amalia ${ }^{2}$ \\ Fakultas Psikologi, Universitas Muhammadiyah Malang \\ e-mail: ${ }^{1}$ ajartrisna94@gmail.com
}

\begin{abstract}
The rise of transportation network companies in Indonesia provides another alternative solutions for effective and efficient transportation needs for the community. However, like any organization can not be seperated from the conflict that accompanies along with it. On of them is related to job satisfaction. Job satisfaction is seen as a collectio of feelings or attitudes of individuals towards several aspect of their work. The purpose of this study was to determine the level of job satisfaction on online motorcycle taxi drivers in Kota Malang by using of quantitative descriptive approach. This study involved 181 online motorcycle taxi drivers with sample determination using purposive sampling technique. Data collections uses Minnesota Satisfaction Questionnaire shortform. Based on the analysis result show the level of job satisfaction of online motorcycle taxi drivers is categorized as low with percentage of $51.9 \%$ and $48.1 \%$ categorized as high. 2) this study also saw no significant difference in job satisfaction in term of work status and length of work (job status $p=0.074$; length of work $p=0.201$ with a significant level of 5\%).
\end{abstract}

KEYWORDS job satisfaction, drivers, online motorcycle taxi

CITATION Sanubari, F., \& Amalia, S. (2019). Gambaran Kepuasan Kerja pada Pengemudi Layanan Jasa Transportasi Ojek Online. Cognicia, 7, (1), 77-94.

Transportasi merupakan pendukung kegiatan manusia dan sudah menjadi salah satu kebutuhan mendasar manusia yang tak terpisahkan dengan kehidupan manusia itu sendiri. Transportasi adalah kegiatan pemindahan barang atau orang dari satu tempat ke tempat lain (Abbas, 1993). Dengan adanya transportasi, manusia terdorong untuk dapat melakukan suatu mobilisasi atau perpindahan dengan cepat, efektif, dan efisien hingga akhirnya manusia mencapai peradaban yang bisa kita rasakan saat ini. Meski demikian, tuntutan untuk peningkatan kualitas dan akses pada transportasi terus meningkat seiring dengan bertambahnya manusia yang bergantung pada mobilitas sebagai sumber daya penunjang kehidupan mereka.

Bentuk transportasi yang tersedia di Indonesia pada umumnya dapat diklasifikan ke dalam tiga jenis. Jenis pertama misalnya adalah transportasi darat seperti kendaraan bermotor; bus, kereta api, angkutan umum, taksi, ojek motor, dan seterusnya. Sebagai contoh serta yang ditarik oleh hewan seperti kuda, pedati, sapi, kerbau, dst. Jenis kedua adalah transportasi udara seperti pesawat terbang, dan terakhir transportasi air seperti kapal, perahu dan rakit. Meskipun terdapat banyak jenis dan pilihan transportasi yang tersedia, transportasi darat umumnya adalah yang paling dibutuhkan untuk mobilitas seharihari untuk menunjang aktifitas dan 
perekonomian masyarakat. Tingginya kebutuhan akan mobilitas masyarakat belum tentu diimbangi oleh ketersediaan transportasi umum yang aman dan nyaman, akibatnya warga terdorong untuk memiliki kendaraan bermotor pribadi baik itu sepeda motor atau mobil. Ruas dan badan jalan yang sulit bertambah, dan tingginya pertumbuhan jumlah kendaraan pribadi tersebut pada gilirannya meningkatkan kemacetan (Rasetyono, 2016).

Kemacetan lalu lintas ini berdampak ketidakpastian dalam segi waktu dan biaya [ CITATION Eka14 \1 1033 ]. Penggunaan transportasi umum dapat menjadi salah satu upaya untuk menekan kemacetan lalu lintas. Namun demikian, tawaran solusi tersebut relatif belum menunjukkan hasil yang memuaskan. Sebab transportasi umum juga tidak terlepas dari adanya masalahmasalah seperti jadwal yang tidak tepat, rute yang belum banyak, lonjakan penumpang yang berlebih di jamjam sibuk, kondisi kendaraan yang buruk, serta cara mengemudi yang sembarangan dan membahayakan keselamatan (Tamin, 1999). Kebutuhan masyarakat akan transportasi umum untuk mobilitas keseharian yang mudah, aman dan nyaman serta berpotensi mengurangi macet inilah yang berusaha dijawab oleh bisnisbisnis startup yang sedang berkembang.

Bersama dengan perkembangan sains, teknologi dan komunikasi yang cukup pesat seperti mesin, gawai dan internet dewasa ini dan tuntutan mobilitas pada masyarakat modern mendorong lahirnya berbagai macam inovasi di bidang transportasi. Inovasi ini memberikan perubahan pada sistem transportasi dalam segala bentuknya. Beberapa tahun belakangan ini, bisnis-bisnis startup memanfaatkan perkembangan teknologi komunikasi tersebut dan menginovasikan mode transportasi baru yang memadukan mode tranposrtasi yang sudah ada seperti ojek motor dan taksi dengan teknologi internet dan smartphone. Transportasi baru ini dikenal dengan transportasi online.

Tujuan dari pengembangan mode tranpsortasi ini tidak hanya sebagai menjawab tantangan akan pilihan transportasi alternatif yang mudah secara aksesnya, nyaman, dan aman untuk memenuhi kegiatan dan kebutuhan masyarakat seharihari saja, akan tetapi juga dapat mengurangi angka pengangguran dengan membuka lapangan kerja dan menyerap banyak tenaga kerja (Aziza, 2017). Satu hal yang unik dalam model bisnis transportasi online atau online ini, sistem hubungan kerja antara perusahaan dengan pengemudi ojek online adalah kemitraan (Indyaswari \& Putra, 2017; Sonhaji, 2018). Menurut Kamus Besar Bahasa Indonesia versi daring (KBBI, 2019) kemitraan memiliki arti perihal hubungan (jalinan kerja sama dan sebagainya) sebagai mitra. Sedangkan arti kata mitra itu sendiri adalah teman, sahabat, kawan kerja, pasangan kerja, dan rekan. Perusahaan diposisikan sebagai Mitra I sedangkan pengemudi ojek online berada di posisi Mitra II.

Kerjasama kemitraan ini menerapkan sistem bagi hasil antara pengemudi dengan perusahaan. Perusahaan hanya bertindak sebagai penyedia media penghubung antara konsumen dan pengemudi berupa aplikasi. Dengan sistem ini, pengemudi tidak mendapatkan gaji dari perusahaan melainkan mendapatkan penghasilan dari pengguna jasa. Jadi, semakin banyak konsumen yang dilayani maka semakin banyak pula hasil yang didapatkan.

Selain dari penghasilan yang didapatkan dari jasa yang diberikan kepada konsumen, pengemudi juga bisa mendapatkan penghasilan tambahan dari adanya 
sistem poin yang mana bisa ditukarkan dengan bonus setiap harinya. Sistem poin tersebut berbeda-beda di setiap perusahaan penyedia layanannya namun secara umum konsepnya sama yaitu poin didapatkan setiap pengemudi berhasil menyelesaikan suatu layanan yang disediakan. Setiap layanan yang disediakan memiliki jumlah poin yang berbeda-beda pula yang jika sudah dikumpulkan mencapai standar yang ditentukan oleh pihak perusahaan, maka poin tersebut bisa ditukarkan dengan syarat beberapa ketentuan yang mesti telah dipenuhi oleh pengemudi.

Kehadiran inovasi transportasi online ini menjadi populer di masyarakat meskipun sempat diwarnai pro dan kontra, namun hal itu tampaknya terkesampingkan dengan berbagai kelebihankelebihan yang ditawarkannya. Salah satunya adalah sifatnya yang ondemand yang mana transportasi dapat diatur tujuan dan tempat penjemputannya melalui aplikasi pemesanan langsung dari gawai konsumen di manapun dan kapanpun selama masih dalam lingkup operasi dari penyedia layanan. Binis penyedia layanan transportasi ini tidak hanya menyediakan layanan transportasi seperti ojek dan taksi online saja, namun juga mengembangkan ranah jasa lain seperti pengantaran barang, dokumen, dan paket; sebagai pesan dan pengantaran makanan; kecantikan, pijat, pembelian obat dan masih banyak lagi lainnya.

Perusahaan besar yang berada di balik layanan transportasi online ini diantaranya adalah Grab dan Gojek. Bisnis transportasi online ini sendiri telah tersebar setidaknya hampir di seluruh provinsi di Indonesia. Berbeda dengan Gojek yang cenderung hanya tersedia di kotakota besar (Lestari, 2018), Grab menyediakan jasa ojek onlinenya di banyak kotakota baik kota besar maupun kecil (Pertiwi, 2017). Hal ini selain menggambarkan betapa besarnya bisnis layanan transportasi di Indonesia, juga menunjukkan ketatnya kompetisi di antara kedua perusahaan dalam merebut pasar konsumen sebagai pengusung transportasi alternatif terbaik.

Salah satu upaya perusahaan untuk dapat bersaing dengan perusahaan penyedia layanan adalah yakni dengan memberikan dan meningkatkan mutu layanan yang berkualitas. Berbagai promo dan diskon pun diberikan untuk memanjakan konsumen. Namun, di samping memberikan mutu pelayanan yang baik demi kepuasan konsumen, perusahaan juga memliki tanggungjawab yang terkait dengan peningkatan kinerja dari sumber daya manusianya. Pada dasarnya, untuk mencapai keberhasilan visi dan misi perusahaan tidak terlepas dari dukungan dan kerjasama yang baik dari komponen perusahaan. Sehingga apabila perusahaan ingin meningkatkan kinerja dan kualitas pelayanan maka perusahaan selayaknya dapat menciptakan lingkungan kerja yang yang baik, seperti pemberian gaji, pengawasan dan bimbingan yang baik, adanya jaminan baik itu kesehatan maupun keselamatan, dan lainlain sebagainya.

Namun demikian, sebagai moda bisnis yang terbilang baru, bisnis transportasi online ini tidak terlepas dari konflikkonflik yang terjadi. Ada berbagai macam fenomena konflikkonflik yang terjadi pada trasnportasi online ini semenjak beroperasi di Indonesia. Misalnya, para pengemudi ojek online tercatat pernah menggelar aksi demonstrasi di Surabaya pada 2016 silam, meminta Pemprov Jawa Timur menerbitkan pergub yang dapat melindungi hak mereka, terutama soal kelayakan tarif (Addi, 2018). Pada tahun 2017, ribuan pengemudi trasnsportasi online menggelar aksi massa 
menyuarakan aspirasi dan keluhan atas kesamaan rasa dirugikan akibat kebijakan perusahaan (Nurita, 2017).

Tak berhenti di situ, pada Maret 2018 silam perkumpulan pengemudi transportasi online kembali berkumpul berdemonstrasi di Jakarta, lagi-lagi tuntutannya seputar pada kebutuhan regulasi dan kenaikan tarif (Bintoro, 2018; Fitriani, 2018). Kemudian di kota Solo pun terjadi tindakan demonstrasi dan aksi mogok kerja serupa dikarenakan adanya penurunan tarif yang dilakukan pihak perusahaan tanpa adanya sosialisasi, selain itu menurut pengemudi ojek online penurunan tarif tersebut membuat keuntungan mereka menjadi sangat minim (Isnanto, 2018) Selain demonstrasi, di Kota Malang misalnya para pengemudi ojek online salah satu perusahaan layanan transportasi tersebut melakukan migrasi yang cukup besar ke perusahaan pesaing dikarenakan masalah penghasilan atau bonus yang didapatkan (Andi, 2018).

Mengingat fakta bahwa terdapat demonstrasi atau unjuk rasa yang berulang dalam beberapa tahun terakhir, diduga ada indikasi ketidakpuasan kerja pada pengemudi ojek online. Hal tersebut terjadi karena adanya kesenjangan antara harapan dan kenyataannya atau dengan kata lain karena adanya ketidaksesuaian antara kenyataan dengan kebijakan perusahaan. Para pengemudi ojek online menganggap bahwa mereka sebagai mitra perusahaan hanyalah slogan semata, tidak sesuai dengan apa yang terjadi yang sebenarnya.

Kepuasan kerja pada dasarnya mengacu pada evaluasi menyeluruh sikap atau penilaian seseorang terhadap pekerjaanya (Weiss, 2002). Dikarenakan menyangkut sikap, kepuasan kerja mencakup berbagai hal seperti kondisi dan kecenderungan perilaku seseorang. Selain itu, kepuasan kerja pada dasarnya juga bersifat individual yang artinya setiap individu memiliki tingkat kepuasan yang berbedabeda pada hal yang sama.

Robbins (2012) menjelaskan faktorfaktor yang mempengaruhi kepuasan kerja diantaranya adalah tantangan kerja, kondisi kerja yang mendukung, sistem kerja yang adil, dan rekan kerja yang mendukung. Kepuasan kerja seseorang dalam suatu perusahaan sangat mungkin akan berbeda-beda. Perbedaan ini dikarenakan adanya kebutuhan individu yang berbeda-beda pula atau situasi dan kondisi dalam perusahaan yang dapat menyebabkan seseorang menjadi puas dalam bekerja.

Kepuasan kerja bagi karyawan merupakan faktor yang penting karena kepuasan yang diperolehnya akan turut menentukan sikap positif terhadap pekerjaan. Ketidakpuasan kerja karyawan akan menyebabkan timbulnya berbagai masalah yang terjadi baik bagi diri karyawan itu sendiri maupun pada perusahaan tempat ia bekerja. Kepuasan kerja secara langsung berdampak pada kesehatan dan kesejahteraan individu. Lebih lanjut lagi terdapat korelasi antara kepuasan kerja dengan gejala fisik, keadaan emosional seperti kecemasan, dan depresi (Barlings \& Burns, 2009; Begley \& Czajka, 1993; Jex \& Gudanowski, 2010).

Menurut penelitian, beban kerja yang berlebih dapat menyebabkan karyawan mengalami gangguan kecemasan, kinerja yang buruk dan kepuasan kerja yang menurun (Haryanto \& Rahardjo, 2014). Pengemudi ojek online sebenarnya tidak diharuskan untuk dapat mencapai poinpoin tertentu sebagai imbalan performa kerja mereka, namun penghasilan sebagai pengemudi ojek online dirasakan tidak cukup dan 
mesti ditutupi dengan mengejar poin-poin tersebut untuk dapat ditukarkan dengan bonus. Hal tersebut dikeluhkan oleh sebagian pengemudi dikarenakan menguras banyak tenaga dan waktu mereka.

Di sisi lain, Tiffin (As'ad, 2004) berpendapat bahwa kepuasan kerja berhubungan erat dengan sikap karyawan terhadap pekerjaannya, situasi atau lingkungan kerja, dan kerjasama antara pihak pimpinan dengan sesama karyawan. Hal ini sangat penting karena karyawan yang tidak mendapat kepuasan dalam bekerja akan terdorong untuk bekerja seadanya atau seenaknya, datang terlambat, mangkir/bolos kerja, tidak mencintai pekerjaannya, unjuk kerja dengan membawa pekerja lain yang mengalami hal sama dan bahkan mungkin tidak bisa bertahan di tempat kerjanya atau turnover. Sebuah penelitian yang menyangkut dengan kepuasan kerja (Tariq, Ramzan, \& Riaz, 2013) mengungkapkan bahwa beban kerja, gaji, dan stress di tempat kerja, menyebabkan karyawan menuju ketidakpuasan yang selanjutnya berakibat pada turnover.

Selain itu, kepuasan kerja secara keseluruhan memiliki hubungan yang positif terhadap produktivitas, keuntungan profit, dan kepuasan pelanggan (Harter, Schmidt, \& Hayes, 2002). Sependapat dengan hal itu, penelitian lanjut menemukan hubungan kepuasan kerja dengan kepuasan pelanggan dan peringkat kualitas layanan pelanggan pada tingkat individu (Antonaki \& Trivellas, 2014; Brown \& Lam, 2008; Söderlund, 2017).

Kepuasan kerja juga berkaitan dengan keadilan dan kelayakan akan balasan yang setimpal yang diterima karyawan terhadap kinerjanya di perusahaan. Apabila pemberian kompensasi sudah adil dan layak, maka akan muncul kepuasan kerja yang mana nantinya akan meningkatkan kinerja karyawan itu sendiri. Laura (2012) mengatakan bahwa kompensasi yang diterima karyawan baik langsung maupun tidak langsung secara bersamasama (secara simultan) mempunyai pengaruh signifikan terhadap kepuasan kerja karyawan. Semakin besar kompensasi yang diterima maka semakin besar motivasi karyawan untuk meningkatkan kinerjanya, sehingga kepuasan kerja akan tercapai di tingkat karyawan.

Namun demikian selama ini gaji atau penghasilan yang didapatkan belum sesuai dengan keinginan dan harapan beberapa pengemudi ojek online. Penghasilan mereka tersebut dirasakan tidak sebanding dengan jerih payah mereka dalam bekerja. Munandar (2006) mengatakan equitable reward atau imbalan yang dirasakan adil akan menentukan kepuasan kerja karyawan. Pemberian kompensasi dan bonus dari perusahaan mencerminkan upaya untuk memotivasi dan mempertahankan mitra pengemudi ojek online. Namun karena dirasakan kurang adil dan tidak layak bagi mereka akhirnya pengemudi ojek online merasakan ketidakpuasan.

Ketiadaan perlindungan hukum yang jelas dan regulasinya yang sampai sekarang masih di proses dan belum juga rampung menimbulkan kekhawatiran bagi pengemudi ojek online. Beragam unjuk rasa sudah dilakukan untuk menyuarakan atas terpenuhinya hakhak mereka ini. Pengemudi ojek online diangap berbeda dengan ojek konvensional lainnya dimana adanya sistem kemitraan antara pengemudi dengan perusahaan yang menerapkan bagi hasil. Ketiadaan regulasi hukum dan undangundang yang mengatur jenis transportasi yang tergolong baru ini dikhawatirkan akan merugikan bagi pengemudi. Perlindungan hukum bagi pekerja 
dimaksudkan untuk menjamin hak dasar pekerja dan menjamin akan kesetaraan dan kesamaan perlakuan tanpa adanya diskriminasi atas dasar apapun, terutama kemungkinan akan penyalahgunaan kewenangan pihak perusahaan terhadap pengemudi ojek online. Kekhawatiran akan ketidakamanan pekerjaan yang menyangkut dengan ketiadaan perlindungan hukum ini berpengaruh terhadap bagaimana kepuasan pengemudi ojek online dengan pekerjaan mereka.

Salah satu persoalan yang mendapat perhatian dalam setiap organisasi atau perusahaan adalah bagaimana memahami kebutuhan dan kepuasan setiap individu yang akan menjadi salah satu keberhasilan organisasi. Namun demikian, dalam kenyataan di lapangan, seringkali kepuasan kerja para karyawan atau tenaga kerja tersebut cenderung diabaikan oleh pihak perusahaan, apabila kondisi tersebut tidak dengan segera dilakukan penanganan dan langkah antisipasi yang baik, maka lambat laun upaya pencapaian visi dan misi perusahaan tidak dapat tercapai dengan maksimal.

Berdasarkan dari uraian di atas, jelas bahwa kepuasan kerja memilki peran penting dalam dunia kerja. Locke (dalam Munandar, 2006) menjelaskan kepuasan kerja sebagai perasaan senang atau keadaan emosional positif terhadap pekerjaan yang berasal dari penilaian seseorang terhadap pekerjaan atau pengalaman dari pekerjaannya. Kepuasan atau ketidakpuasan itu mencerminkan penimbangan atas dua nilai yang bertentangan yaitu pertentangan apa yang dipersepsikan antara apa yang diinginkan dengan apa yang diterima. Menurut Locke individu akan merasa puas atau tidak puas tergantung bagaiamana ia mempersepsikan adanya kesesuaian ataukah pertentangan antara keinginankeinginan dan hasil yang ia dapatkan.

Munandar (2006) dalam bukunya menjelaskan salah satu teori mengenai kepuasan kerja adalah Teori Ketidaksesuaian (Discrepancy Theory). Menurut Locke, teori ketidaksesuaian mengungkapkan bahwa kepuasan atau ketidakpuasaan kerja dari beberapa aspek pekerjaan menggunakan dasar pertimbangan dua nilai (values), yaitu (1) ketidaksesuaian yang dipersepsikan antara apa yang diinginkan individu dengan apa yang dia terima dalam kenyataannya; dan (2) apa pentingnya pekerjaan yang diinginkan oleh individu tersebut. Kepuasan kerja secara keseluruhan bagi individu adalah jumlah dari kepuasan kerja dari setiap aspek pekerjaan dikalikan dengan derajat pentingnya aspek pekerjaan individu. Kemudian, Locke juga mengatakan bahwa perasaan puas atau tidak puas yang dimiliki oleh individu sangat bersifat pribadi, karena perasaan tersebut muncul tergantung dari cara indidu mempersepsikan ketidaksesuaian atau pertentangan antara keinginankeinginan dan hasil yang telah dicapainya.

Terdapat 3 dimensi utama dalam kepuasan kerja yang berdasarkan pada apa yang dikembangkan oleh Weiss (Arnold \& Daniel, 1986) yaitu Intrinsic, Extrinsic, dan General Satisfaction yang masingmasing terdiri dari beberapa aspek di dalamnya. Aspekaspek tersebut berjumlah 20 dengan penjabarannya seperti berikut: (1) Activity, merupakan segala macam bentuk aktivitas yang dilakukan dalam bekerja dan seberapa jauh pekerjaan tersebut menyibukkan pekerja; (2) Independence, merupakan kemandirian dalam melakukan pekerjaan seperti melakukan pekerjaan dengan caranya sendiri; (3) Variety, merupakan variasi yang dapat dilakukan dalam pekerjaan seperti kesempatan untuk melakukan aktivitas lain di luar pekerjaan itu sendiri; (4) 
Social Status, merupakan derajat sosial dan harga diri yang dirasakan dalam pekerjaan; (5) SupervisionHuman Relations, merupakan pengawasan keapsa bawahan atau kemampuan atasan dalam membina hubungan dengan bawahan; (6) SupervisionTechnical, merupakan pengawasan secara teknis atau yang berhubungan dengan pekerjaan; (7) Moral Values, merupakan nilainilai moral yang dimiliki dalam melakukan pekerjaan; (8) Security, merupakan kepastian kerja, keamanan atau rasa aman yang dirasakan terhadap pekerjaannya; (9) Social Service, merupakan kesempatan untuk dapat membantu orang lain; (10) Authority, merupakan kesempatan mengatur/memimpin orang lain; (11) Ability Utillization, merupakan kesempatan untuk melakukan sesuatu dengan menggunakan kemampuan, keahlian dan keterampilan yang dimilikinya; (12) Company Policies and Practices, merupakan kebijakan yang diterapkan oleh perusahaan dan seberapa jauh hal tersebut memuaskan pekerja; (13) Compensation, merupakan segala bentuk kompensasi atau gaji yang diterima; (14) Advancement, merupakan kemajuan atau perkembangan yang dicapai selama bekerja atau promosi dalam pekerjaan; (15) Responsibility, merupakan kebebasan untuk menggunakan keputusannya sendiri atau tanggung jawab yang diemban; (16) Creativity, merupakan kesempatan unutk mencoba metode sendiri dalam menyelesaikan tugas; (17) Working Conditions, merupakan keadaan/kondisi lingkungan tempat kerja baik itu waktu kerja, fasilitas, lokasi, dan lainlain sebagainya; (18) CoWorkers, merupakan dengan rekan kerja, yang terlibat langsung dalam pekerjaan; (19) Recognition, merupakan pengakuan yang diterima atas hasil kerja yang dicapai; (20) Achievement, merupakan tingkat keberhasilan/kepuasan yang diperoleh dalam pekerjaannya.

Banyak faktor - faktor yang mempengaruhi kepuasan kerja karyawan. Faktorfaktor itu sendiri dalam peranannya memberikan kepuasan kepada karyawan tergantung pada pribadi masingmasing individu itu sendiri. Faktor - faktor yang memberikan kepuasan kerja menurut Locke (dalam Munandar, 2006) adalah: (1) Intrinsik pekerjaan, Pekerjaan yang menuntut kecakapan atau kemampuan yang tinggi dibandingkan kemampuan yang dimiliki individu, atau adanya tuntutan pribadi yang tidak dapat dipenuhi akan menimbulkan frustasi dan perasaan gagal akhirnya berujung pada ketidakpuasan kerja; (2) Gaji atau penghasilan, sejauh mana imbalan yang diterima dirasakan adil. Apabila penghasilan dipersepsikan adil didasarkan pada tuntutantuntutan pekerjaannya, tingkat keterampilan individu, serta standar gaji yang berlaku pada kelompok pekerjaan tertentu, maka akan menimbulkan kepuasan kerja; (3) Penyeliaan. Kepuasan kerja yang muncul ketika hubungan yang terbentuk antara atasan atau supervisor dan karyawan adalah hubungan yang positif, atau sejauh mana penyelia membantu tenaga kerja secara supportif; (4) Rekan-rekan kerja yang mendukung. Ialah kepuasan kerja yang timbul karena adanya interaksi sosial dengan pekerja lain, seperti dapat diajak bekerjasama, orang yang menyenangkan, dan juga dapat memberikan dukungan moral dan sosial; (5) Kondisi kerja yang menunjang. Bekerja dalam ruangan yang sempit, panas, kondisi cahaya atau penerangan, dan lainlain sebagainya, akan menimbulkan keengganan dalam bekerja. Maka dari itu pihak perusahaan perlu memfasilitasi karyawannya.

McShane menjelaskan bahwa untuk memahami bagaimana konsekuensi dari ketidakpuasan kerja adalah dengan menggunakan model Exit Voice Loyalty Neglect 
(EVLN), yang merupakan 4 cara respon karyawan terhadap ketidakpuasan (McShane \& Von, 2009). Adapun responrespon tersebut ialah : (a) Keluar (Exit), yaitu perilaku yang ditujukan untuk meninggalkan organisasi, termasuk mencari posisi baru di tempat lain dan atau mengundurkan diri; (b) Aspirasi (Voice), adalah tindakan yang sifatnya untuk mengubah keadaan daripada lari dari masalah yang mengakibatkan ketidakpuasan itu. Bentuknya bisa secara aktif dan konstruktif untuk berusaha memperbaiki kondisi, termasuk menyarankan perbaikan, mendiskusikan masalah dengan atasan, dan bahkan kebentuk konfrontasi seperti membentuk koalisi atau serikat pekerja, unjuk rasa, dan lainlain; (c) Kesetiaan (Loyalty), berbeda dengan voice yang aktif menyuarakan perubahan, loyalty secara umum adalah secara pasif tetapi tetap optimis menunggu membaiknya keadaan atau kondisi, termasuk membela organisasi/perusahaan ketika berhadapan dengan kecaman eksternal dan mempercayai organisasi dan manajemennya untuk "melakukan hal yang benar" dengan kata lain menunggu masalah tersebut diselesaikan oleh orang lain; (d) Pengabaian (Neglect), secara pasif membiarkan kondisi menjadi lebih buruk, termasuk ketidakhadiran atau keterlambatan yang dilakukan secara terusmenerus, kurangnya usaha untuk memperbaiki, dan meningkatnya angka kesalahan. Hal ini dianggap sebagai perilaku pasif yang dapat berdampak negatif bagi perusahaan.

Munculnya pembaruan terkait ketersediaan layanan transportasi semakin menarik minat masyarakat dalam pemenuhan kebutuhan transportasi setiap harinya. Sebuah perusahaan yang melayani dalam bidang transportasi harus menyiapkan segala fasilitasfasilitas yang dapat menunjang konsumen yang menggunakan jasa perusahaan tersebut. Tidak hanya kepuasan konsumen tetapi perusahaan juga harus menyediakan fasilitasfasilitas yang dapat membantu kinerja mitra ojek online yang bekerjanya tidak di dalam kantor seperti kebanyakan pekerja lainnya, akan tetapi berada di jalan raya. Selain fasilitas, pihak perusahaan juga harus selalu memperhatikan bagaimana kepuasan kerja sumber daya manusianya.

Karyawan dalam hal ini berfungsi sebagai penunjang tercapainya tujuan perusahaan yang memiliki pikiran, perasaan, dan keinginan yang mempengaruhi sikap terhadap pekerjaan yang dibebankan. Sikap karyawan tersebut dikenal dengan istilah kepuasan kerja yang ditimbulkan oleh pekerjaan, lingkungan, dan kebutuhannya. Maka kepuasan kerja memiliki arti penting bagi setiap perusahaan yang karena akan menjadi tolak ukur keberhasilan perusahaan dalam memenuhi kebutuhan karyawannya. Kepuasan kerja pada karyawan bergantung pada beberapa faktor yang mempengaruhinya, diantaranya adalah ciri pekerjaan, kompensasi, hubungan dengan penyelia, hubungan dengan rekan kerja, dan kondisi kerja yang mendukung.

Aziri (2011) menyatakan bahwa ketidakpuasan karyawan terhadap pekerjaannya dapat diwujudkan dalam beberapa hal yaitu dampak terhadap produktivitas yang rendah sehingga membuat keuntungan perusahaan menurun, dampak terhadap ketidakhadiran (Absenteisme) dan keluarnya tenaga kerja (Turnover), meningkatnya kecelakaan kerja, meningkatnya pemogokan kerja, meningkatnya keluhan serta dampaknya terhadap demonstrasi karyawan, bahkan tindak kriminal seperti sabotase yang dilakukan oleh karyawan. 
Penelitian terdahulu telah menunjukkan adanya pengaruh antara kepuasan kerja terhadap kinerja (Noor, 2001). Kepuasan kerja karyawan yang tinggi ditunjukkan pada iklim organisasi yang berorientasi pada prestasi kerja, afiliasi, sedangkan pada iklim organisasi yang berorientasi pada kekuasaan menunjukkan kepuasan kerja yang rendah (Zahreni, 2008). Kepuasan kerja juga berpengaruh signifikan pada kinerja karyawan karena pengawas juga ikut berperan dalam kinerja karyawan (Syaiin, 2008).

\section{METODE}

Penelitian ini menggunakan metode kuantitatif desriptif, yaitu metode yang digunakan untuk meneliti populasi atau sampel tertentu yang mana pengumpulan datanya akan dilakukan dengan menggunakan instrumen penelitian kemudian dianalisis dan diinterpretasikan menggunakan metode statistik (Sugiyono, 2013). Tujuan dari penelitian deskriptif ini adalah untuk membuat deskripsi atau gambaran secara sistematis, faktual dan akurat mengenai faktafakta, sifatsifat serta hubungan antar fenomena yang diselidiki (Winarsunu, 2009). Teknik pengambilan sampling pada penelitian ini menggunakan NonProbality Sampling, yang yang mana tidak memberi peluang/kesempatan sama bagi setiap unsur atau anggota populasi untuk dipilih menjadi sampel (Sugiyono, 2013). Adapun pendekatan pengambilan sampel yang digunakan adalah Purposive Sampling, suatu Teknik penentuan sampel dengan pertimbangan tertentu menurut kriteria yang sudah ditentukan oleh peneliti.

Jumlah sampel dalam penelitian ini adalah sebanyak 181 pengemudi ojek online di kota Malang. Kriteria subjek penelitian merupakan individu baik lakilaki maupun perempuan dengan kisaran umur 2040 tahun ke atas, bekerja sebagai pengemudi transportasi/ojek online, bekerja secara fulltime maupun sekedar sampingan atau paruh waktu.

Penelitian ini mengkaji satu variabel mandiri yaitu kepuasan kerja, yang mana peneliti melakukan penilaian terhadap pengemudi ojek online terkait perasaan positif atau negatif terhadap pekerjaannya. Instrumen dalam penelitian ini menggunakan kuesioner Minnesotta Satisfaction Questionnaire (MSQ) Shortform. Skala ini terdiri atas 20 item pertanyaan atau pernyataan yang mewakili 20 aspek kepuasan kerja yang telah dijelaskan sebelumnya di atas. Skala ini merupakan bentuk adaptasi yang disesuaikan dengan kondisi dan bahasa tempat di mana penelitian dilakukan. Tanggapan yang diberikan berupa 5 poin skala likert dengan 5 pilihan jawaban yakni STS (sangat tidak setuju), TS (tidak setuju), N (netral/raguragu), S (setuju), dan SS (sangat setuju).

Berdasarkan uji validitas dan reliabilitas hasil tryout skala yang dilakukan kepada 50 pengemudi ojek online di kota Malang menunjukkan bahwa skala MSQ memiliki jumlah item valid sebanyak 18 dari 20 item. Adapun indeks validitasnya berkisar 0,305-0,715 dan indeks reliabilitas 0,843. Dari hasil tersebut itemitem yang digunakan dalam skala penelitian ini dinyatakan sudah reliabel atau dapat dihandalkan (Azwar, 2014).

\section{HASIL}

Berdasarkan hasil penelitian yang dilakukan terhadap 181 pengemudi ojek online yang tersebar di Kota Malang dengan beberapa kriteria yang sudah ditentukan sebelumnya, didapatkan data demografis yang dipaparkan pada table di bawah ini: 
Tabel 1. Deskripsi Subjek Penelitian

\begin{tabular}{ccc}
\hline \multicolumn{1}{c}{ Kategori Demografi } & Frekuensi & Persentase \\
\hline Jenis Kelamin & & \\
$\quad$ Laki-laki & 159 & $87.8 \%$ \\
Perempuan & 22 & $12.2 \%$ \\
\hline Usia & & \\
20 - 25 tahun & 63 & $34.8 \%$ \\
26-30 tahun & 52 & $28.7 \%$ \\
31 - 35 tahun & 24 & $13.3 \%$ \\
36-40 tahun & 21 & $11.6 \%$ \\
\hline Status Pekerjaan & & \\
Penuh Waktu & 81 & $44.8 \%$ \\
$\quad$ Paruh Waktu & 100 & $55.2 \%$ \\
\hline Lama Bekerja & & \\
$\quad>\mathbf{1}$ Tahun & 82 & $45.3 \%$ \\
$<\mathbf{1}$ Tahun & 99 & $54.7 \%$ \\
\hline Total & $\mathbf{1 8 1}$ & $\mathbf{1 0 0} \%$ \\
\hline
\end{tabular}

Dari tabel 1 di atas dapat diketahui bahwa jumlah subjek didominasi oleh subjek yang berjenis kelamin lakilaki sebanyak 159 orang atau sebesar 87,8\% dan 22 orang sisanya adalah perempuan atau sebesar $12,2 \%$. Rentang usia subjek berkisar antara 20 hingga 40 tahun ke atas dengan jumlah terbanyak didominasi oleh subjek yang berusia 20 hingga 25 tahun berjumlah 63 orang atau sebesar 34,8\%, kemudian disusul subjek yang berusia 26 hingga 30 tahun dengan 52 orang atau sebesar $28,7 \%$, lalu usia 31 hingga 35 tahun berjumlah 24 orang atau sebesar 13,3\%, dan subjek berusia berkisar 36 hingga 40 serta 40 tahun ke atas yang masingmasing memiliki jumlah subjek yang sama yakni 21 orang atau sebesar $11,6 \%$.

Dari kategori status pekerjaannya, jumlah yang mendominasi adalah pada subjek yang bekerja secara paruh waktu sebanyak 100 orang atau sebesar 55,2\% dan sisanya adalah subjek yang bekerja secara penuh waktu yang berjumlah 81 orang atau $44,8 \%$. Adapun dari lamanya bekerja, subjek yang telah bekerja kurang dari 1 tahun berjumlah 82 orang atau sebesar 45,3\% dan yang telah bekerja lebih dari1 tahun berjumlah 99 orang atau sebesar $54,7 \%$.

Hasil menunjukkan bahwa subjek yang memiliki kepuasan kerja yang tinggi terhadap pekerjaan mereka sebagai pengemudi ojek online sebanyak 87 orang dengan persentase sebesar 48,1\%. Sedangkan yang dikategorikan memiliki kepuasan kerja yang rendah adalah sebanyak 94 orang atau sebesar 51,9\%. Sehingga dapat diketahui bahwa subjek dengan kategori kepasuan kerja yang rendah lebih banyak daripada subjek yang memiliki kepuasan kerja tinggi.

Selain itu, peneliti juga melakukan analisa tambahan mengenai analisa uji beda yang membandingkan kepuasan kerja berdasarkan status pekerjaan kemudian diperoleh nilai uji beda $t=1,215$ dengan nilai signifikansi $(p)$ sebesar $0.074<0,05$. Dapat disimpulkan bahwa tidak ada perbedaan kepuasan kerja berdasarkan status pekerjaan. Selain membandingkan dari status pekerjaan, hasil analisa uji beda pada lama bekerja 
juga menunjukkan nilai $t=0,719$ dengan nilai signifikansi $(p)$ sebesar $0,201<0,05$. Maka dari hal tersebut dapat diartikan bahwa tidak ada perbedaan kepuasan kerja berdasarkan lama bekerja. Subjek yang bekerja dengan waktu kurang dari 1 tahun tidak menunjukkan adanya perbedaan secara signifikan dengan subjek yang bekerja dengan waktu lebih dari 1 tahun.

\section{DISKUSI}

Berdasarkan hasil analisa data yang telah dilakukan terhadap data penelitian, diperoleh hasil bahwa kepuasan kerja pada pengemudi mitra ojek online didapatkan memiliki kepuasan kerja yang rendah, dengan jumlah sebanyak 51,9\%. Dapat dikatakan bahwa sebagian pengemudi mitra ojek online mengalami ketidakpuasan kerja. Mengapa sebagian pengemudi ojek online mengalami ketidakpuasan kerja? Perlu digaris bawahi bahwa kepuasan kerja pada umumnya bersifat individualistis yang artinya tingkat kepuasan kerja individu berbedabeda antara satu dengan lainnya. Kepuasan kerja itu sendiri terdiri dari beberapa faktor yang dapat mempengaruhinya. Antara satu individu dengan yang lainnya mungkin merasakan ketidakpuasan di satu faktor, namun justru puas di faktor yang lain.

Adapun dari hasil penelitian juga didapatkan bahwa ada berbagai macam respon yang diberikan subjek berbedabeda pada setiap aspek dari kepuasan kerja dari Sangat Tidak Setuju, Tidak Setuju, Netral, Setuju, dan Sangat Setuju. Terdapat 3 aspek yang mana ratarata sebagaian besar subjek merespon pada kisaran Netral hingga Sangat Tidak Setuju. Adapun ketiga aspek tersebut ialah aspek Activity, Security, dan Authority.

Pada aspek Activity pengemudi ojek online kebanyakan merasa memberikan respon yang Netral. Hal ini bisa jadi disebabkan oleh adanya perbedaan perspektif antar individu dalam memandang kesibukan dalam pekerjaannya. Namun, beberapa pekerja/pengemudi ojek online ini merasa aktivitas dalam pekerjaan mereka ini dinilai terlalu sibuk. Sebagaimana yang dilaporkan oleh beberapa pengemudi yang peneliti wawancarai mengemukakan bahwa mereka, pengemudi ojek online, mesti menginvestasikan waktu dan tenaga yang lebih dari biasanya untuk bisa mendapatkan bonus di penghujung hari. Oleh karena itu bisa dibilang bahwa seorang pengemudi ojek online memiliki jam kerja ratarata melebihi pekerja kantoran (Fanggidae, Sagala, Ningrum, \& Prakarsa, 2016).

Dalam penelitian Dall'Ora, et al (2015) menyatakan bahwa kemungkinan pekerja meninggalkan pekerjaan mereka dikarenakan ketidakpuasan kerja meningkat $31 \%$ kepada perawat yang bekerja lebih dari 12 jam dibandingkan perawat yang bekerja kurang dari 8 jam per harinya. Peneliti lain seperti Sari (2019) mengkonfirmasi hal yang serupa, bahwa fleksibilitas kerja mempunyai pengaruh tidak langsung terhadap kepuasan kerja seseorang. Hanya saja banyaknya waktu dan tenaga yang dikeluarkan oleh pengemudi ojek online selama bekerja merupakan beban kerja yang mesti ditanggung. Namun, penelitian (Janssen, 2001; Van \& Janssen, 2002) mengemukakan bahwa beban kerja itu sendiri tidak memprediksikan kepuasan kerja, akan tetapi persepsi individu terhadap beban kerja itulah yang dapat menentukan tingkat kepuasan kerja seseorang. 
Dalam hal ini terdapat pertentangan yang mana meskipun pengemudi ojek online memiliki jam kerja yang fleksibel dikarenakan memiliki waktu yang bebas untuk bekerja sesuai keinginan mereka, beban kerja yang cenderung ringan karena memiliki kebebasan untuk bisa menonaktifkam aplikasi mereka agar tidak menerima permintaan layanan dari konsumen sehingga pengemudi ojek online bisa berhenti sejenak untuk sekedar istirahat, namun pada kenyataannya untuk mendapatkan penghasilan yang layak para pengemudi ojek online mesti bekerja lebih dari 8 jam untuk dapat menyelesaikan target performa mereka untuk dapat ditukarkan sebagai bonus tambahan pada setiap harinya. Hal ini menunjukkan bahwa pengemudi ojek online alihalih memiliki waktu yang fleksibel dan pekerjaan yang tidak begitu menyita waktu, justru terjebak dalam situasi yang dirasa menekan secara sistemis oleh adanya aturan dan kebijakan dari perusahaan. Misalnya yaitu target performa yang mesti dicapai oleh pengemudi ojek online dan mempertahankannya untuk mendapatkan bonus tambahan setiap harinya.

Begitu halnya pada aspek Security, para pengemudi ojek online kebanyakan juga merespon Netral pada pertanyaan yang menyangkut aspek tersebut. Aspek ini menjelaskan sejauh mana kepuasan pekerja terhadap kepastian akan pekerjaan mereka. Subjek merespon Netral atau ragu-ragu mungkin dikarenakan melihat bagaimana kondisi pekerjaan mereka sekarang yang masih belum jelas. Insekuritas atau perasaan ketidakamanan akan kerja timbul karena sistem kepegawaian yang 'fleksible' yang tidak secara permanen dan jangka panjang memberi kejelasan mengenai gaji dan tunjangan pensiun (Surie \& Koduganti, 2016). Selain itu, ketiadaan perlindungan hukum dan perundangundangan yang dapat menjamin pengemudi ojek online juga turut menyumbangkan insekuritas. Memang perusahaan sudah mengupayakan dalam memberikan jaminanjaminan seperti kesehatan dan keselamatan, namun tampaknya hal tersebut belum begitu memberikan kepuasan bagi pengemudi ojek online. Persaingan dan kompetisi antar perusahaan dan pengemudi ojek online, serta bertambahnya jumlah pengemudi ojek online turut menambah kekhawatiran para pengemudi terhadap pekerjaan mereka. Kekhawatiran itu cukup beralasan dengan semakin bertambahnya jumlah pengemudi maka semakin banyak pula pesaing mereka dalam memberikan layanan dan pada akhirnya berimbas pada banyaknya penghasilan mereka.

Di sisi lain apabila seorang pengemudi ojek online menolak suatu permintaan dari konsumen dan kemudian konsumen memberikan rating yang rendah yang mana secara tidak langsung akan mengurangi kesempatan mereka untuk menerima bonus. Konsekuensinya bagi para pengemudi ojek online adalah menerima sanksi berupa suspend sementara yang apabila terjadi terus menerus dan berulang tanpa adanya perubahan akan kinerja mereka, maka hubungan kemitraan antara pengemudi dengan perusahaan akan diputus atau diberhentikan. Hal ini tidak adil bagi sebagian dari pengemudi dikarenakan adanya pengambilan keputusan sepihak yang dilakukan perusahaan yang hanya berdasarkan pada laporan dari konsumen saja dan tidak mendengarkan penjelasan dari pihak pengemudi. Sistem suspend ini memang menjadi salah satu hal yang kerap dikeluhkan mitra pengemudi ojek online. Namun, pihak perusahaan membantah akan hal itu (Addi, 2018; Lingga, 2018), kebijakan tersebut menurut pihak perusahaan sudah tertuang di kontrak perjanjian awal dengan 
pengemudi ojek online, seharusnya mitra pengemudi sudah mengetahui hal tersebut. Barangkali hal ini terjadi mungkin dikarenakan adanya komunikasi yang kurang baik antara perusahaan dengan mitra pengemudinya.

Padahal, komunikasi baik itu adalah komunikasi ke atas, ke bawah maupun secara horizontal yang memiliki peran penting dalam suatu organisasi atau perusahaan. Sebagai contoh, perusahaan dapat keuntungan secara kompetitif dengan cara 'memanfaatkan' ide dan masukan dari pekerja terkait dengan bagaimana meningkatkan pelayanan (Botero \& Van Dyne, L., 2009) maupun kinerja dan komitmen terhadap organisasi (Chamanzamin, 2013). Selain itu, dalam penelitian lain (Satriowati, Paramitha, \& Hasiholan, 2016) menunjukkan bahwa komunikasi berpengaruh terhadap kepuasan kerja pekerja. Kurangnya komunikasi yang baik di antara pihak perusahaan dengan pengemudi ini mungkin mengakibatkan adanya rasa ketidakamanan dan ketidakstabilan dalam pekerjaan yang berimbas pada kepuasan kerja si pengemudi ojek online. Pengemudi ojek online yang merasa tidak puas akan mengevaluasi kembali pekerjaannya dan berpikir untuk mencari alternatif pekerjaan lain.

Aspek terakhir yang sebagian besar subjek merespon Sangat Tidak Setuju adalah aspek Authority, aspek ini seperti yang sudah dibahas di bab sebelumnya adalah kesempatan yang mana seseorang punya otoritas atau kuasa yang dapat dibebankan kepada orang lain. Aspek ini tidak dialami oleh pengemudi ojek online dikarenakan pengemudi ojek online tidaklah mempunyai hierarki pekerjaan, semua pengemudi ojek online adalah sama. Sehingga bisa dikatakan para pengemudi ojek online tidak mendapat kepuasan kerja yang bersumber dari aspek tersebut, melainkan ada aspek lain yang sekiranya mempengaruhi tingkat kepuasan kerja mereka.

Selain respon subjek yang cenderung Netral dan Sangat Tidak Setuju pada beberapa aspek, terdapat aspekaspek dalam penelitian ini yang subjek respon dengan baik. Diantaranya adalah aspek Independence, Social Service, Responsibility, dan Achievement. Pada aspek aspek tersebut sekiranya dapat dilihat adanya kesinambungan antara satu sama lain. Aspek Independence menunjukkan kemandirian atau melakukan pekerjaan dengan cara mereka sendiri, salah satunya ialah kebebasan dalam menentukan waktu ia bekerja. Salah satu alasan banyaknya orang untuk menjadi pengemudi ojek online adalah keleluasaan dalam menentukan jam kerja tersebut, sehingga besar kemungkinan mengapa pada aspek Independence ini memiliiki kepuasan yang tinggi.

Aspek Responsibility, Social Service, dan Achievement bisa dikatakan saling berkaitan. Pengemudi ojek online memiliki tanggung jawab untuk dapat memberikan pelayanan yang terbaik untuk konsumen, pelayanan yang baik berdampak pada kepuasan dan loyalitas konsumen. Dalam penelitian Mar'ati (2016) pada konsumen Gojek di Surabaya didapatkan bahwa kualitas layanan jasa transportasi ojek online berpengaruh tehadap kepuasan pelanggan. Hal senada juga ditemukan oleh Dewa (2018), kualitas layanan jasa Grabcar mempunyai efek positif terhadap kepuasan pelanggan. Begitu pula dengan penelitian Al Rasyid (2017) yang menyatakan hal serupa. Selama pengemudi memberikan pelayanan yang baik, konsumen menjadi puas akan pelayanannya dan memberikan reward atau rating yang sesuai akan kinerja 
dari pengemudi ojek online. Pemberian rating tersebut bisa dikatakan sebagai laporan performa atau kinerja dari si pengemudi itu sendiri.

Hubungan antara konsumen dan pihak pemberi jasa adalah hubungan yang timbal balik. Konsumen yang memberikan rating tinggi akan berdampak positif pada laporan performa dari pengemudi ojek online. Selama pengemudi menjaga kinerja mereka dengan baik, rating tersebut tidak akan turun yang pada nantinya berdampak pada bonus yang didapatkan. Dengan menyelesaikan suatu layanan jasa sembari berusaha mencapai target yang sudah ditentukan membuat pengemudi memberikan layanan terbaik yang bisa ia berikan.

Kemudahan untuk dapat menjadi pengemudi ojek online membuat orang ramai untuk mendaftarkan diri mereka. Ada banyak alasan memotivasi mereka untuk bergabung, salah satunya adalah kebebasan untuk menentukan waktu bekerja dan penghasilan yang mau didapatkan. Mudah bagi mereka yang mendedikasikan waktunya untuk menjadi pengemudi ojek online secara penuh, namun bagaimana dengan mereka yang menjadikan pekerjaan sebagai pengemudi ojek online itu sampingan. Menurut hasil penelitian ini, kepuasan kerja yang ditinjau dari status pekerjaannya, yang mana status pekerjaan tersebut adalah paruh waktu dan penuh waktu didapatkan bahwa tidak ada perbedaan yang signifikan $(0,074)$ antara pengemudi ojek online yang bekerja secara penuh waktu dengan yang paruh waktu. Mungkin hal ini dapat disebabkan status pekerjaan yang paruh waktu dan penuh waktu pada pekerejaan sebagai pengemudi ojek online samasama memiliki waktu yang fleksibel dalam menjalankan pekerjaannya. Hanya saja pengemudi ojek online yang bekerja secara penuh memiliki posisi yang lebih menguntungkan dikarenakan memiliki waktu yang lebih banyak dibandingkan dengan rekan-rekan pengemudi yang bekerja secara paruh waktu. Hal ini dikarenakan faktor finansial seperti penghasilan dan bonus yang didapat akan berbeda.

Selain itu, kepuasan kerja ditinjau dari lamanya bekerja didapatkan hasil bahwa tidak adanya perbedaan, yang mana nilai signifikansi yang didapatkan 0,342. Mitra ojek online yang bekerja $<1$ tahun tidak memiliki perbedaan dengan mitra ojek online yang bekerja $>1$ tahun. Hal ini bertentangan dengan apa yang Robbins dan Judge (2012) kutip dalam buku mereka yang menyatakan bahwa semakin lama karyawan berada dalam satu pekerjaan, maka kecil kemungkinan bagi karyawan tersebut untuk mengundurkan diri. karyawan dengan masa kerja lama cenderung memiliki kemampuan atau pengalaman yang lebih banyak dibandingkan dengan karyawan yang masih belum terlalu lama. Kondisi tersebut membuat karyawan dengan masa kerja yang lebih lama cenderung lebih mudah untuk menyelesaikan tugas-tugasnya dan merasa lebih senang terhadap pekerjaannya. Namun bukan berarti hal ini tidak menutup kemungkinan akan terjadinya turnover yang dilakukan oleh pengemudi ojek online. Hal ini juga dapat dilihat bahwa semakin lama pengemudi ojek online bekerja tidak menjamin akan memiliki kepuasan kerja yang tinggi pula.

\section{SIMPULAN DAN IMPLIKASI}

Tujuan dari penelitian ini adalah untuk mengetahui gambaran kepuasan kerja pada pengemudi ojek online. Hasil penelitian ini menunjukkan bahwa dari 181 subjek, sebanyak 51,9\% memiliki kepuasan kerja yang rendah dan subjek yang memiliki 
kepuasan kerja yang tinggi sebesar 48.1\%. selain meggambarkan kepuasan kerja, penelitian ini juga menemukan bahwa tidak ada perbedaan yang signifikan antara kepuasan kerja pengemudi ojek online yang bekerja secara paruh waktu dengan pengemudi yang bekerja secara penuh waktu dengan nilai signifikasi 0.074. Selain itu, dari lama bekerja juga menunjukkan bahwa tidak ada perbedaan yang signifikan antara kepuasan kerja pengemudi ojek online yang bekerja lebih dari 1 tahun dengan pengemudi yang bekerja kurang dari 1 tahun dengan nilai signifikasi 0.342.

Implikasi praktis dari penelitian ini adalah bagi perusahaan penyedia layanan transportasi berbasis online ini untuk dapat memperhatikan kembali kepuasankepuasan kerja pada mitra pengemudinya. Mengidentifikasi awal mengenai apa yang bisa mengakibatkan ketidakpuasan kerja dirasa perlu dilakukan agar dapat menyusun hal apa saja yang mesti dilakukan untuk menanggulangi dan mencegah hal tersebut terjadi di kemudian hari. Hal tersebut demi keberlangsungan organisasi dengan tercapainya visi dan misi perusahaan. Karena suatu organisasi atau perusahaan tak lain bisa dipisahkan dengan unsurunsur sumber daya manusianya untuk dapat berjalan dengan baik. Manfaat bagi pengemudi ojek online, penelitian ini diharapkan mampu memberikan gambaran mengenai kepuasan kerja sebagai bentuk telaah diri sejauh mana mereka puas akan pekerjaan mereka sebagai pengemudi ojek online tersebut. Selain itu dapat mengupayakan untuk menyuarakan hal tersebut ke perusahaan dengan cara yang lebih baik lagi.

Adapun keterbatasan pada penelitian ini diantaranya adalah jumlah subjek didominasi oleh subjek yang berjenis kelamin lakilaki. Oleh sebab itu untuk penelitian selanjutnya dapat menggunakan subjek perempuan lebih banyak atau setara untuk dapat melihat apakah adanya perbedaan diantara keduanya. Selain itu, waktu dalam mengumpulkan data penelitian yang singkat sehingga jumlah sampel yang terkumpul dirasa terlau sedikit sehingga belum dapat digeneralisasikan ke populasi keseluruhan. Kemudian, jumlah aspek yang cukup banyak dan mungkin saling tumpang tindih antara satu sama lain membuat beberapa aspek tidak memiliki kontribusi yang berarti sehingga kurang tajam dalam menggambarkan bagaimana kepuasan kerja pada pengemudi ojek online sehingga penelitian ini belum bisa digeneralisasikan untuk ke populasi yang lebih besar. Penelitian selanjutnya perlu memikirkan aspek-aspek kepuasan kerja yang sekiranya lebih sedikit namun dapat mengekplorasi lebih jauh dan secara jelas bagaimana kepuasan kerja pada pengemudi ojek online.

\section{REFERENSI}

Abbas, S. (1993). Manajemen Transportasi. Jakarta: Rajawali Press.

Addi, M. I. (2018). Gojek Menyatakan Sedang Kaji Ulang Sistem Suspend Driver. Retrieved March 19, 2019, from Tirto.id website: https://tirto.id/gojekmenyatakansedangkajiulangsistemsuspenddriverdapg

Al Rasyid, H. (2017). Pengaruh Kualitas Layanan Dan Pemanfaatan Teknologi Terhadap Kepuasan Dan Loyalitas Pelanggan GoJek. Jurnal Ecodemica: Jurnal Ekonomi, Manajemen, Dan Bisnis, 1(2), 210-223.

Andi, H. (2018). Perkara bonus, driver Grab berbondongbondong beralih ke Gojek. Retrieved December 10, 2018, from kompas.com website: https://regional.kompas.com/read/2018/12/03/14283921/perkarabonusdrivergrabberbond ongbondongberalihkegojek 
Antonaki, X. E., \& Trivellas, P. (2014). Psychological contract breach and organizational commitment in the Greek banking sector: the mediation effect of job satisfaction. Procedia: Social and Behavioral, 148, 354-361.

Arnold, H. J., \& Daniel, C. F. (1986). Organizational Behavior. McGrawHil.

As'ad, M. (2004). Seri Ilmu Sumber Daya Manusia: Psikologi Industri Edisi KeEmpat. Yogyakarta: Liberty Yogyakarta.

Aziri, B. (2011). Job Satisfaction: A Literature review management research and practice. 3(4).

Aziza, K. S. (2017). Pemerintah harus dukung transportasi online karena serap tenaga kerja. Retrieved December 27, 2018, from Kompas.com website: https://ekonomi.kompas.com/read/2017/08/03/135728926/pemerintahharusdukungtransp ortasionlinekarenaseraptenagakerjaAzwar, S. (2014). Reliabilitas dan Validitas Edisi 4. Yogyakarta: Pustaka Pelajar.

Barlings, T., \& Burns, U. (2009). Factor affecting retention and turnover among Nurses in America. American Journal of Nursing, 43(4), 345-354.

Begley, T. M., \& Czajka, J. M. (1993). Panel analysis of the moderating effects of commitment on job satisfaction, intent to quit, and health following organizational change. Journal of Applied Psychology, 78(4), 552-556.

Bintoro, A. (2018). ojek online kembali demo masih tuntut tarif dan payung hukum. Retrieved July 30, 2018, from CNN Indonesia website: https://www.cnnindonesia.com/teknologi/20180327122208384286197/ojekonlinekembalid emomasihtuntuttarifdanpayunghukum

Botero \& Van Dyne, L., I. C. (2009). Botero, I. C., \& Van Dyne, L. (2009). Employee voice behavior: Interactive effects of LMX and power distance in the United States and Colombia. Management Communication Quarterly, 23(1), 84-104.

Brown, S. P., \& Lam, S. K. (2008). A metaanalysis of relationships linking employee satisfaction to customer responses. Journal of Retailing, 84, 243-255. Chamanzamin, M. R. (2013). The Relationship Between Communication Skills and Job Performance of The Employess, Fire Managers of Rasht City. Internasional Journal of Business and Behavioral Sciences, 3(2).

Dall'Ora, C., Griffiths, P., Ball, J., Simon, M., \& Aiken, L. H. (2015). Association of 12 h shifts and nurses' job satisfaction, burnout and intention to leave: findings from a crosssectional study of 12 European countries. BMJ Open, 5(9).

Dewa, C. B. (2018). Pengaruh Kualitas Pelayanan dan Promosi Penjualan Jasa Grabcar Terhadap Kepuasan Pelanggan (Studi Kasus Pada Wisatawan di Yogyakarta). Perspektif, 16(1), 1-6.

Fanggidae, V., Sagala, M. P., Ningrum, D. R., \& Prakarsa, P. (2016). ondemand Transport workers in Indonesia. Transformation in Technology, Transformation in Work, 15-44.

Fitriani, F. F. (2018). demo gojek grab ini 3 tuntutan pengemudi ojek online. Retrieved July 28, 2018, from Bisnis.com website: https://jakarta.bisnis.com/read/20180327/77/754749/demogojekgrabini3tuntutanpengemu diojekonline

Harter, J. K., Schmidt, F. L., \& Hayes, T. L. (2002). Businessunitlevel relationship between employee satisfaction, employee engagement, and business outcomes: A metaanalysis. Journal of Applied Psychology, 87, 268-279.

Haryanto, W. D., \& Rahardjo, M. (2014). Pengaruh Stress Kerja dan Motivasi terhadap Kepuasan Kerja (studi pada Perawat RSUD Kota Semarang).

Indyaswari, P. P. T. A., \& Putra, D. N. R. A. (2017). Analisis mengenai hubungan sopir Gojek dengan PT. Gojek Indonesia. Kertha Semaya, Vol 5(2). Isnanto. (2018). tarif diturunkan driver gojek di solo demo dan mogok 3 hari. Retrieved July 28, 2018, from Detik.com website: 
https://news.detik.com/jawatengah/3930219/tarifditurunkandrivergojekdisolodemodanm ogok3hari

Janssen, O. (2001). Fairness perceptions as a moderator in the curvilinear relationships betweenjob demands, and job performance and job satisfaction. Academy of Management Journal, 44(5), 1039-1050.

Jex, R., \& Gudanowski, T. (2010). Job satisfaction among Nurses in general practice. British Nurs J, 23(4), 567-575.

KBBI. (2019). Kemitraan. Retrieved March 2, 2019, from KBBI Daring website: https://kbbi.kemdikbud.go.id/entri/kemitraan

Laura, H. (2012). Pengaruh kompensasi langsung dan tidak langsung terhadap kinerja karyawan (studi kasus di ruang perawatan VIP Anggrek dan ruang perawatan K. RS. Persatuan Gereja Indonesia Cikini Jakarta. Jurnal Ekonomi Dan Ilmu Sosial, 1625.

Lestari, S. H. (2018). sudah kuasai 62 kota di 17 provinsi indonesia gojek bidik target mustahil ini hingga akhir 2018. Retrieved December 21, 2018, from Tribunnews.com website: http://jatim.tribunnews.com/2018/06/25/sudahkuasai62kotadi17provinsiindonesiagojekbi diktargetmustahilinihinggaakhir2018

Lingga, M. A. (2018). GoJek Bantah Jatuhkan Sanksi Sepihak Terkait "Suspend" untuk Driver. Retrieved January 20, 2019, from Kompas.com website: https://ekonomi.kompas.com/read/2018/11/23/220000326/gojekbantahjatuhkansanksisepi hakterkaitsuspenduntukdriver

Ma'arti, C. N. (2016). CHOIRUL MARATI, N. A. F. I. S. A. (2016). Pengaruh kualitas layanan dan harga terhadap kepuasan pelanggan jasa transportasi ojek online (Studi pada konsumen gojek di Surabaya). Jurnal Pendidikan Tata Niaga (JPTN), 3(3).

McShane, S. L., \& Von, G. M. (2009). Organizational Behavior. McGrawHill.

Munandar, A. S. (2006). Psikologi Industri dan Organisasi. Jakarta: UIPress.

Noor, M. R. (2001). Analisis pengaruh kepuasan kerja terhadap kinerja karyawan di PZT Seafer general foods, Kendal. Semarang: Magister Manajemen Universitas Dipenogoro.

Nurita, D. (2017). ribuan pengemudi ojek online berdemo kami mitra bukan jongos. Tempo.Com.

Retrieved

from https://bisnis.tempo.co/read/1036376/ribuanpengemudiojekonlineberdemokamimitrabuk anjongos/full\&view $=$ ok

Pertiwi, W. K. (2017). Grab hadir di 100 kota di indonesia. Retrieved December 21, 2018, from Kompas.com website: https://tekno.kompas.com/read/2017/11/23/10100017/grabhadirdi100kotadiindonesia

Rasetyono, A. P. (2016). IPTEK: Solusi komprehensif atasi kemacetan lalu lintas. Retrieved December 20, 2018, from Ristekdikti.go.id website: https://ristekdikti.go.id/kolomopini/ipteksolusikomprehensifatasikemacetanlalulintas/

Robbins, S. P., \& Judge, T. A. (2012). Perilaku Organisasi. Jakarta: Salemba Empat.

Sari, D. M., \& Fitri, W. (2019). Pengaruh Fleksibilitas Jam Kerja Terhadap Kepuasan Kerja Dengan Komitmen Organisasi Dan Konflik PekerjaanKeluarga Sebagai Variabel Mediasi (Studi Pada Wanita Bekerja Di Kota Surakarta) . Surakarta: IAIN.

Satriowati, E., Paramitha, P. D., \& Hasiholan, L. B. (2016). Pengaruh Gaya Kepemimpinan Transformasional, Kompensasi dan Komunikasi terhadap Kinerja Karyawan dengan Kepuasan Kerja sebagai Variabel Mediasi pada Laundry Elephant King. Journal of Management, 2(2). 
Söderlund, M. (2017). Employee Display of Burnout in the Service Encounter and its Impact on Customer Satisfaction. Journal of Retailing and Consumer Services, 37, 168-176.

Sonhaji, S. (2018). Aspek Hukum Layanan Ojek Online Perspektif UndangUndang Nomor 13 Tahun 2003 Tentang Ketenagakerjaan. Administrative Law \& Governance Journal, 1(4), 371-385.

Sugiyono. (2013). Metode penelitian kuantitatif, kualitatif, dan RED. Bandung: Alfabeta.

Surie, A., \& Koduganti, J. (2016). The Emerging Nature Of Work In Platform Economy Companies In Bengaluru, India: The Case Of Uber And Ola Cab Drivers. EJournal of International and Comparative Labour Studies, 5(3).

Syaiin, S. (2008). Pengaruh kepuasan kerja terhadap kinerja pegawai klinik spesialis bestari medan tahun 2007. Medan.

Tamin, O. Z. (1999). Konsep Manajemen Kebutuhan Transportasi (MKT) Sebagai Alternatif Pemecahan Masalah Transportasi Perkotaan di DKI Jakarta. Sumber, 2025(59), 5. Journal of Regional and City Planning, Vol 10(1).

Tariq, M., Ramzan, M., \& Riaz, A. (2013). The Impact of Employee Turnover on The Efficiency of The Organization. Interdiciplinary Journal of Contemporary Research in Business, 4(9), 700-711.

Van, P. N. W., \& Janssen, O. (2002). Fatigued and dissatisfied or fatigued but satisfied? Goalorientations and responses to high job demands. Academy of Management Journal, 45(6), 1161-1171.

Weiss, H. M. (2002). Deconstructing job satisfaction: Separating evaluations, beliefs and affective experiences. Human Resource Management Review, 173-194.

Winarsunu, T. (2009). Statistik dalam peneltian psikologi dan pendidikan. Malang: UMMPress.

Zahreni, S. (2008). Perbedaan kepuasan terhadap supervisi ditinjau dari gaya pengelolaan supervisor. Medan: Fakultas Psikologi Universitas Sumatera Utara. 115 